\title{
CORPORATE FINANCING BEHAVIOUR OF SHARIAH COMPLIANT E50 SMES. A PANEL DATA APPROACH OF GMM.
}

\author{
Razali Haron ${ }^{1}$
}

* Affiliation:

${ }^{1}$ IIUM Institute of Islamic

Banking and Finance

\begin{abstract}
Motivated by the recent outstanding growth of Islamic Finance in Malaysia, this study aims to investigate the debt financing behaviour of Shariah compliant E50 SMEs in Malaysia covering the existence of target debt, speed of adjustment and factors affecting the adjustment speed to target debt from 2009 to 2013. The Shariah Advisory Council (SAC), has set up certain standard of parameters as guidelines and carried out periodical monitoring in classifying Shariah compliant securities like the prohibition of activities that involve interest (riba), gambling (maisir), uncertainties and speculative trading (gharar). The dynamic model employed and estimated using the Generalized Method of Moment (GMM). Under the dynamic model, the observed debt of a firm should be equal to its optimal debt. However, with the presence of adjustment cost, a firm performs only a partial adjustment to be at the target debt. The model revealed certain determinants significantly influence target debt financing. The positive relationship between tangibility and capital structure yielded in this study enhances Shariah imposition that debt must be asset-backed which means a firm operating under Islamic principles cannot have debt exceeding the tangible assets. This study contributes to the literature and fills the gap by exploring into a relatively new area of debt financing which is the dynamic aspects and also help to enhance the understanding on debt financing behaviour of Shariah compliant SMEs in Malaysia.
\end{abstract}

Keywords: corporate financing, Shariah compliant, Islamic Finance, panel data, GMM

\section{INTRODUCTION}

A financing decision reflects the firm's management strategies of structuring its capital. How a firm finances its operation and what are the factors accounted for a financing decision has well been discussed and examined throughout the years. Several theories have been developed along the way as to understand more of the decisions made on the financing preferences. Each theory presents a different explanation 
of corporate financing under certain conditions, assumptions, and propositions. Modigliani and Miller (1958) is known to be the pioneer to the development of capital structure theories. Since then theoretical frameworks have been developed with contributions mainly aiming at explaining the capital structure decisions of firms.

Literature witnesses a large range of capital structure studies around the globe regardless of the economic landscapes. The fact that the study of capital structure is still inconclusive (Haron, 2014a) and the bits and pieces are still to be explored does open up more research needs in the body of knowledge. Nevertheless, large listed firms have been monopolizing the trend in the capital structure studies due to the accessibility of data (Rajan and Zingales, 1995). In recent years, researchers have begun to shift their attention to small and medium enterprises (SMEs) as the main focus of the study. SMEs have been recognised as being a crucial element to almost all economies in the world, especially to those in developing countries. SMEs in total constitute a large proportion of the economic activity and considered to be an engine of growth in both developed and developing countries (Boocock and Shariff, 2005). In developing countries, concern on the role of SMEs in the development process continues to be in the forefront of policy debates (Cook, 2001) as they comprise a majority of the business population in most countries and therefore play a crucial role in the economy (Mitchell and Reid, 2000). Mac an Bhaird (2010) added that the realization of the significant economic contribution of SMEs has resulted in increased attention focused on the sector from policy makers as well as the academicians.

Amidst the evolution in terms of the development of the corporate finance world itself and the attention given to the SMEs in recent years, the scope of capital structure studies has extended to studying Islamic finance and the Islamic Capital Market (ICM) in particular. As at the end of 2010, the size of Malaysia's ICM was reported to have reached RM1.05 trillion compared to just RM294 billion as at end 2000. The size of Malaysia's ICM is expected to expand further at the average rate of $10.6 \%$ per annum under the second Capital Market Master Plan to reach RM2.9 trillion by 2020. Following its incredible growth, Shariah compliant securities become one of the important elements in ICM. The development of capital market in Malaysia, unlike its other emerging market counterparts is significantly contributed by its ICM with Shariah compliant securities being prominent products of Malaysian ICM (Securities Commission, 2013). This remarkable track record of ICM and Shariah compliant securities have instigated some SMEs in Malaysia to become Shariah compliant especially those which are religiously inclined.

The firm is said to be Shariah compliant when it adheres to the set guidelines and not contradicts with the Shariah principles. In Malaysia, Shariah Advisory Council (SAC), established in 1996 is responsible in outlining and determining the criteria of Shariah compliant firm and also guiding the Securities Commission on Shariah related issues. The selection of Shariah compliant takes place through a screening process based on qualitative and quantitative parameters. The qualitative screening ensures a firm not involved in prohibited core activities like financial services based on riba (interest), gambling and gaming, manufacturing or selling of non-halal products or related products, any activities containing an element of gharar (uncertainty) like conventional insurance, entertainment activities which are non-permissible 
according to Shariah, manufacturing or selling of tobacco-based products or related products, stockbroking or share trading in non-Shariah compliant securities and other activities that are contrary to Shariah principles. The quantitative screening, on the other hand is used to determine the source of profit and revenue of a firm which may come from a mixture of halal (permissible) and haram (non-permissible) activities. If the contribution from non-halal activities exceeds a benchmark set by the SAC, the company will not be classified as Shariah compliant. For those companies whose revenue is tainted by unavoidable non-halal activity, a cleansing mechanism is also predicted to purify their profit. This mechanism requires that a percentage of such incomes to be paid to a charitable organisation, before the distribution of dividends to shareholders. Islamic finance which is governed by Shariah law, divine ethics and guidelines recognizes large profit provided it serves the Maslahah and not merely wealth accumulation of one party only.

Having recognised the importance of a financing decision of a firm through its capital structure, the worldwide recognition of SMEs as the back bone of an economy and the remarkable emergence of the ICM, this study sees the paramount need to investigate the financing decision of the SMEs in Malaysia. This study intends to analyse the capital structure of Shariah compliant SMEs in Malaysia as the number of these firms is increasing in Malaysia (SME Corp. Malaysia, 2013). The Shariah compliant SMEs chosen for this study are the ones which have been awarded with Enterprise 50 (E50) awards. Enterprise 50 is an annual award programme organised by the SME Corporation Malaysia (SME Corp. Malaysia) and Deloitte Malaysia, with supporting sponsorship by RHB Bank Berhad and Telekom Malaysia Berhad (TM) to celebrate and highlight the achievements of enterprising small and medium companies that are well positioned for the future. Each year, 50 winners are selected from amongst the nominations received and the evaluation is based on key financial and non-financial factors. To date, a total of 1,798 companies participated and 550 companies have come out as winners. From this pool of winners, 46 have been listed on Bursa Malaysia and 14 on ACE Market. The fact that the number of SMEs is increasing each year and the limited resources of financial assistance especially from the government have driven this study to give attention to the E50 awarded SMEs. These SMEs demonstrate high potential to contribute significantly to the national economic development (Saarani and Shahadan, 2013) thus it is paramount to understand and have better insights of their financing decisions. Following the recent attraction now on ICM also instigates this study to investigate further the capital structure of these Shariah compliant E50 awarded SMEs.

Apart from examining the capital structure of these SMEs which covers the existence of target debt financing among Shariah compliant E50 SMEs, this study will attempt to investigate the speed of adjustment to target debt financing and the factors affecting the target. These investigations are feasible using a dynamic model. This additional interest and insights will distinct this study from the existing ones in the literature and the findings will contribute significantly to the body of knowledge as well as to practitioners and also perhaps to financing resources of the SMEs. The findings will enrich the current literature thus opens up more potential researches as to further understand this complex relationship between debt financing and firm value, especially among these SMEs as being the back bone of the economy. 


\section{LITERATURE REVIEW THE PERFORMANCE OF SMES IN MALAYSIA}

SMEs have demonstrated a substantial increase in performance with the Gross Domestic Product (GDP) of SMEs consistently outperforms the overall economy. The average annual growth rate is 6.8 percent, compared with 4.9 percent for the whole economy in the period 2004 to 2010 (SME Corp. Malaysia, 2012). SMEs represent 99.2 percent of the total business establishments in the country and contributed 56.4 percent to total employment in the country (Ministry of Finance, 2010), 31.4 per cent of GDP and 22 percent of the country exports (SME Corp. Malaysia, 2010). 93.8\% of companies in the manufacturing sector are SMEs and they contributed $27.3 \%$ to total manufacturing output, $25.8 \%$ to value-added production, own $27.6 \%$ of fixed assets and employ $38.9 \%$ of the country's workforce. It is forecasted that by 2020 , the value added products from SMEs will be worth RM120 billion or $50 \%$ of total production in the manufacturing sector. It is important to note that different countries have different definition of SMEs. This study uses the standardized definition of SMEs set by the National SME Development Council of Malaysia. The National SME Development Council has approved the definitions of SMEs which are based on two criteria, namely: number of fulltime employees or annual sales turnover. Therefore, an enterprise will be classified as SMEs if it meets either the specified number of employees or annual sales turnover definition.

\section{SMEs Financing Scenario}

The 2011 Malaysia Economic Census reported that most SMEs (55.9\%) use their internal funding or from shareholders to finance their operations (Source: Department of Statistics Malaysia). About three quarters (75.6\%) of SMEs financing was for working capital. The financing needs were similar across all sizes, namely microenterprise (74.6\%), small-sized firms $(77.8 \%)$ and medium-sized firms $(74.2 \%)$. Other main activities which required financing $(43.6 \%)$ were for purchase and lease of equipment, machinery, vehicles, computer hardware and software as well as land and buildings. Manan et al. (2011) found that the most critical constraint that small and medium scale manufacturers mention is the lack of sufficient capital to operate the business. In most cases, businesses started using own savings and borrowing from friends and relatives followed by funding from banks.

Compared to large local firms and multinational corporations (MNCs), SMEs have more difficulty in accessing finance partly because their small size and lack of credit worthiness due to the inefficiency of credit markets resulting from problems of asymmetric information (Behr et al., 2011). SMEs tend to face even greater difficulty in developing economies, where capital markets and regulatory frameworks are not fully developed, and financial systems tend to be dominated by banks, which is found to be associated with lower use of financial services by firms of all sizes (Beck et al., 2013). Using data from 2005, Shen et al. (2009) found that in the People Republic of China (PRC), local proper lending authority, competition, credit schemes, and law enforcement are supportive to loan provisions by commercial banks to SMEs. Harvie et al. (2013) studied a sample of 150 questionnaires collected in 2010 from Cambodia, Indonesia, Laos, the PRC, Malaysia, the Philippines, Thailand, and Viet Nam, and found that SMEs in these developing Asian economies tend to depend on internal finance for start-ups and 
business expansion. Banks are not willing to provide loans to small medium entrepreneurs as they present a high risk group. Small medium enterprises can sometimes are not interested to borrow from banks due to the tight procedural process and the length of time it might take to obtain the loan.

The financing experiences of SMEs around the world suggest that smaller firms typically depend on internal finance for initial capital and external finance for liquidity, and studies have noted that banks are the major source of external finance. A survey, conducted under the World Bank Investment Climate for the period of 2002 to 2003 in 38 developing countries in Europe, Asia, Africa and Latin America, confirms the reliance of SMEs on internal finance and retained earnings. Arinaitwe (2006) found that the SMEs have lower level of external finance (debts over total assets) as a high proportion of their assets were financed primarily by family and friends (internal finance). Nonetheless, the comparative ratio of debt and equity indicates that debt was dominant over equity in the SMEs financial structure.

In Malaysia, the non-availability of finance has been the most frequently cited problem encountered by SMEs, and it is also a crucial issue to many of them. Most studies reported that majority of SMEs indicated inadequate working capital and lack of access to commercial lending as their major problem. Banks in Malaysia play an important role as a source of credit. Private finance companies and family or friends come second after banks as another source of financing. Surprisingly, subsidized loan schemes under some government agencies and other similar institutions benefited only few, though the resources are abundantly available.

As far as Islamic SME-financing in Malaysia is concerned, Ismail and Razak (2003) had examined the pattern of debt-equity financing to the SMEs extended by the financial institutions (FIs) over the period of 1993 to 1997. The samples were drawn from the list of SMEs financed by the FIs throughout the period of study. The data, obtained from the original records of the FIs investment, include the firms' name, age, firms' code, total assets, total shareholders' funds, date of registration, number of employees, the amount as well as the type of financing provided and the activity being financed. The study revealed that debt financing inclusive of mainly debt financing (Ijarah, Bai' bithaman ajil, and Murabahah) represent the larger fraction of the number of financing as well as the total amount of financing than equity finance. The study also showed that debt financing by financial institutions go to smaller and younger firms. In terms of usage of funds, the findings indicated two categories of funds used, namely financing of fixed assets and operating capital, and both categories acquire more than 95 percent of all financings via debt. The study concluded that SMEs prefer to choose debt financing rather than equity to set up and expand their businesses. Similar finding was also reported by Manan et al. (2011) where a significant number of SMEs in Malaysia sought Islamic debt financing modes such as Murabahah, Bai' bithaman Ajil and Ijarah as sources of external capital.

\section{CAPITAL STRUCTURE OF SHARIAH COMPLIANT FIRMS}

The basic structure of theoretical exposition of determining capital structure of a firm operating under Islamic principles is similar to the conventional Pecking Order Theory (Ahmed, 2007). Like the conventional case, Shariah compliant can also be classified into debt and equity. The debt financing is in form of Ijarah (lease contract) or Murabahah (sale 
contract of asset at a mark-up). Equity financing is in form of Mudarabah (silent partnership) and Musyarakah (partnership that share both in capital and management). Being Shariah firms in nature, Ahmed also outlined the constraints of financing instruments and parameters set by Islamic principles. The first constraint is when firm wants to optimize debt financing; while at the same time, manager has to minimize total cost of financing. Since Shariah firm will have some ethical dimension, managers are assumed strive for efficiency and minimize cost of financing assets. The second constraint mainly is about maintaining debt ratio so it will not exceed ratio of tangible assets to total assets. The debt financing has to be asset backed, thus, is a real transaction. Therefore, any expansion in operations require partly expansion of its tangible assets because debt constraints implies that fund are not available in form of debt from bank unless firm has good reputation, collateral and good financial standing. Derigs and Marzban (2008) on the other hand pointed out despites the prohibition of riba (interest based transaction) which is very much associated with debt financing, contemporary Shariah scholars do not strictly impose a zero debt in a capital structure. Instead, it is encouraged to try to establish a somewhat reasonable financial ratio with a range of 30-40 percent to be an acceptable maximum debt to total asset ratio, which is a commonly agreed ratio among the scholars. The SAC has imposed debt ratio of $33 \%$ to be the acceptable debt level effective from November, 2013.

Empirical research on capital structure in Islamic countries has generally been limited to single-country studies. Abraham (2013) found that among banks in Saudi Arabia, domestically owned banks have lower leverage than banks with significant foreign ownership. Given that much of the foreign ownership in the banks in this study was from Western non-Islamic countries, the study suggested that Islam may influence capital structure. In one of the few multi-country studies on capital structure in Islamic countries, Omet and Mashharawe (2003) found that firms in Kuwait, Jordan, Oman and Saudi Arabia generally have low debt ratios. However, because they did not compare them with firms in non-Islamic countries, it is not clear if the low debt ratios are a general phenomenon of all firms in developing countries or due to a specific influence of Islam. Little research has been done regarding debt maturity structure in firms in Islamic countries. Aggarwal and Yousef (2000) found, based on their review of data from studies on banking in Iran, Jordan, Malaysia and Egypt, that the vast majority of Islamic debt instruments issued for short-term debt rather than for long-term debt. They proposed agency costs and moral hazard as an explanation for the preference for short-term lending by banks in Islamic countries.

\section{Capital Structure Determinants}

Several firm level determinants have been commonly employed in explaining the financing decision of firms in the literature such as non-debt tax shield (NDTS), asset tangibility, profitability, business risk, firm size, growth opportunity, liquidity and share price performance. Based on past literature, this study hypothesizes the following relationship between each determinant and debt financing. $\mathrm{H}_{1}$ : negative relationship with NDTS; $\mathrm{H}_{2}$ : positive relationship with asset tangibility, $\mathrm{H}_{3}$ : negative relationship with profitability; $\mathrm{H}_{4}$ : positive relationship with business risk; $\mathrm{H}_{5}$ : positive relationship with firm size; $\mathrm{H}_{6}$ : negative relationship with growth 
opportunity; $\mathrm{H}_{7}$ : negative relationship with liquidity and $\mathrm{H}_{8}$ : positive relationship with share price performance. The body of knowledge has commonly agreed that firms do practice target debt financing and tend to be off the target from time to time due to random shocks. Therefore, $\mathrm{H}_{9}$ : firms adjust to be at the target debt from time to time. Being deviated, firms will strive to be back on their target for value maximization thus demand for investigations on factors influencing the speed of adjustment to target. Several firm level factors affecting the adjustment speeds have been studied like the distance between target and present debt level, firm size, growth and profitability. Following past literature, this study hypothesizes the following relationship between determinants and adjustment speeds. $\mathrm{H}_{10}$ : negative relationship with distance; $\mathrm{H}_{11}$ : positive relationship with firm size; $\mathrm{H}_{12}$ : positive relationship with growth and $\mathrm{H}_{13}$ : positive relationship with profitability.

\section{DATA AND METHODOLOGY}

This study employs a panel data for a period from 2009 until 2013 for 41 Shariah compliance SMEs (out of 52 E50 SMEs as at 31 December 2014) listed on Bursa Malaysia where firm level data is sourced from the annual reports of each firm. Of these sample firms, 33 firms are listed in the main market while the remaining 8 in the ACE market. Following Titman and Wessels (1988), debt is defined as the ratio of total debt, long term debt and short term debt to total asset (book value). Following literature, eight firm specific factors affecting target debt financing are incorporated which are non-debt tax shield (NDTS), tangibility, profitability, business risk, firm size, growth, liquidity and share price performance while for factors affecting speed of adjustment are distance, firm size, growth and profitability.

\section{TARGET DEBT FINANCING}

This study postulates that a dynamic model is able to ascertain the existence of target debt financing on Shariah compliance SMEs in Malaysia. Based on the dynamic partial adjustment model (see for examples, Drobetz and Wanzenried, 2006; Haron, 2014b), this study assumes that a set of explanatory variables influence the target debt financing for a firm as in (1).

$$
\operatorname{Lev}_{\text {it }}^{*}=\mathrm{F}\left(\mathrm{X}_{\mathrm{it}}, \mathrm{X}_{\mathrm{i}}, \mathrm{X}_{\mathrm{t}}\right)
$$

The observed leverage of firm $i$ at time $t\left(\operatorname{Lev}_{\mathrm{it}}\right)$ should be equal to the optimal leverage, that is, $\operatorname{Lev}_{\mathrm{it}}=\mathrm{Lev}_{\mathrm{it}}{ }^{*}$ and this implies that $\operatorname{Lev}_{\mathrm{it}}-\mathrm{Lev}_{\mathrm{it}{ }^{-} 1}=\mathrm{Lev}_{\mathrm{it}}{ }^{*}-\mathrm{Lev}_{\mathrm{it}-1}$. The adjustment costs significantly impact the adjustment process and allow only partial adjustment, as in this study, $\delta$ is expected to be less than 1 , represented in (2).

$$
\operatorname{Lev}_{\mathrm{it}}-\mathrm{Lev}_{\mathrm{it}-1}=\mathrm{d}_{\mathrm{it}}\left(\operatorname{Lev}_{\mathrm{it}} *-\mathrm{Lev}_{\mathrm{it}-1}\right)
$$


where $\delta_{\mathrm{it}}$, is known as the speed of adjustment, it represents the convergence degree of $\operatorname{Lev}_{\mathrm{it}}$, to its optimal value with restriction that $\left|\delta_{\mathrm{it}}\right|<1$, which is a condition that $\operatorname{Lev}_{\mathrm{it}} \rightarrow \operatorname{Lev}_{\mathrm{it}} *$ as $\mathrm{t} \rightarrow \infty$. The firm's behaviour is represented by (3) below.

$$
\operatorname{Lev}_{i t}^{*}=\sum_{n=1}^{N} \beta_{k} X_{k i t}+\varepsilon_{i t}
$$

Combining Equation (2) and (3), the following is derived,

$$
\begin{aligned}
& \operatorname{Lev}_{i t}=\operatorname{Lev}_{i t-1}+\delta_{i t}\left(\operatorname{Lev}_{i t}^{*}-\operatorname{Lev}_{i t-1}\right) \\
& \operatorname{Lev}_{i t}=\operatorname{Lev}_{i t-1}+\delta_{i t} \operatorname{Lev}_{i t}^{*}-\delta_{i t} \operatorname{Lev}_{i t-1} \\
& \operatorname{Lev}_{i t}=\left(1-\delta_{i t}\right) L e v_{i t-1}+\delta_{i t}\left(\sum_{n=1}^{N} \beta_{k} X_{k i t}+\varepsilon_{i t}\right) \\
& \operatorname{Lev}_{i t}=\left(1-\delta_{i t}\right) L e v_{i t-1}+\sum_{n=1}^{N} \delta_{i t} \beta_{k} X_{k i t}+\delta_{i t} \varepsilon_{i t}
\end{aligned}
$$

To simplify, (7) can also be written as,

$$
L e v_{i t}=\lambda_{0} L e v_{i t-1}+\sum_{n=1}^{N} \lambda_{k} X_{k i t}+\mu_{i t}
$$

where $\lambda_{0}=1-\delta_{\mathrm{it}}, \lambda_{\mathrm{k}}=\delta_{\mathrm{it}} \beta_{\mathrm{k}}$, and $\delta_{\mathrm{it}} \varepsilon_{\mathrm{it}}=\mu_{\mathrm{it}}\left(\right.$ where $\mu_{\mathrm{it}}$ has the same properties as $\left.\varepsilon_{\mathrm{it}}\right)$.

We further extend the model to study the factors affecting speed of adjustment to the target debt financing.

$$
\begin{aligned}
\mathrm{Y}_{\mathrm{it}} & =\delta_{\mathrm{it}} \mathrm{Y}^{*}{ }_{\mathrm{it}}+\left(1-\delta_{\mathrm{it}}\right) \mathrm{Y}_{\mathrm{it}-1}+\varepsilon_{\mathrm{it}} \\
& =\left(1-\alpha_{0}-\alpha_{\mathrm{k}} \mathrm{Z}_{\mathrm{it}}\right) \mathrm{Y}_{\mathrm{it}-1}+\left(\alpha_{0}+\alpha_{\mathrm{k}} \mathrm{Z}_{\mathrm{it}}\right)\left(\sum_{n=1}^{N} \beta_{k} X_{k i t}\right)+ \\
\mathrm{Y}_{\mathrm{it}} & =\left(1-\alpha_{0}\right) \mathrm{Y}_{\mathrm{it}-1}-\alpha_{\mathrm{k}} \mathrm{Z}_{\mathrm{it}} \mathrm{Y}_{\mathrm{it}-1}+\alpha_{0} \sum_{n=l}^{N} \beta_{k} X_{\text {itit }}+\alpha_{k} \sum_{n=1}^{N} \beta_{k} Z_{i t} X_{k i t}+\varepsilon_{\mathrm{it}}
\end{aligned}
$$

\section{RESULT AND DISCUSSION}

This section presents the empirical results of the dynamic capital structure model estimated based on the Generalized Method of Moments (GMM) by Arellano and Bond (1991). 
Table 1: Determinants of Target Debt Financing

\begin{tabular}{|c|c|c|c|}
\hline Independent & TD/TA & LTD/TA & STD/TA \\
\hline \multirow[t]{2}{*}{ Debt(-1) } & $0.1977^{* * *}$ & $0.5746 * * *$ & $-0.2138 * * *$ \\
\hline & [6.2179] & [4.9994] & {$[-3.3459]$} \\
\hline \multirow[t]{2}{*}{ NDTS } & 1.5666 & -0.5295 & 2.2023 \\
\hline & [1.1891] & {$[-0.6345]$} & [1.4806] \\
\hline \multirow[t]{2}{*}{ Tangibility } & -0.1198 & 0.2133 & $0.3528^{*}$ \\
\hline & {$[-1.2238]$} & [1.5832] & [1.6792] \\
\hline \multirow[t]{2}{*}{ Profitability } & $-0.2177^{* *}$ & 0.1108 & -0.0804 \\
\hline & {$[-2.5782]$} & [1.1989] & {$[-0.5236]$} \\
\hline \multirow[t]{2}{*}{ Business Risk } & $0.0009 *$ & -0.0001 & 0.0000 \\
\hline & [1.6794] & {$[-0.1620]$} & [0.0010] \\
\hline \multirow[t]{2}{*}{ Firm Size } & $0.0701 *$ & 0.0218 & -0.0271 \\
\hline & [1.8793] & [0.6054] & {$[-0.4889]$} \\
\hline \multirow[t]{2}{*}{ Growth } & 0.0024 & $-0.0248 * * *$ & -0.0011 \\
\hline & [0.5933] & {$[-3.3684]$} & {$[-0.0906]$} \\
\hline \multirow{2}{*}{ Liquidity } & $-0.0095 * *$ & 0.0097 & -0.0259 \\
\hline & {$[-2.5592]$} & [0.8048] & {$[-1.4507]$} \\
\hline \multirow[t]{2}{*}{ Share Price Performance } & 0.0012 & $0.0804 * * *$ & -0.0098 \\
\hline & {$[0.1506]$} & [4.6360] & {$[-0.3015]$} \\
\hline \multirow[t]{2}{*}{ AR(1) m-Statistic } & $-2.0282^{* *}$ & $-1.9721^{* *}$ & -1.3571 \\
\hline & {$[-0.34456]$} & {$[-0.3007]$} & {$[-0.1539]$} \\
\hline \multirow[t]{2}{*}{ AR(2) m-Statistic } & -0.9385 & 0.6898 & -0.9348 \\
\hline & {$[-0.10631]$} & [0.0298] & [0.1579] \\
\hline Wald (Joint) $\chi^{2}$ & $105.8075^{* * *}$ & $180.80225^{* * *}$ & $71.3357^{* * *}$ \\
\hline \multirow[t]{2}{*}{ J-statistic } & 11.3079 & 10.5652 & 4.2459 \\
\hline & {$[p=0.2552]$} & {$[p=0.1587]$} & {$[p=0.6434]$} \\
\hline No. of Observations & 199 & 199 & 199 \\
\hline
\end{tabular}

Source: Author's own.

Existence and Determinants of Target Capital Structure and Speed of Adjustment

The estimated coefficient of the debt $(-1)$ is significant for all debt definitions $(p=0.01)$ and this indicates the existence of target debt financing of Shariah compliance SMEs in Malaysia. The existence of target debt ratio is agreeable with the Shariah scholars' opinions of having reasonable debt ratio in the capital structure rather than zero debt as pointed out by Derigs and Marzban (2008). Several factors significantly influence the target debt financing of these SMEs. Tangibility is found to be positively related to debt financing $(p=0.10) . \mathrm{H}_{2}$ is thus supported. This positive relationship supports the trade-off theory that tangibility or asset structure of a firm should be positively associated to debt (Rajan and Zingales, 1995). This positive relationship enhances Shariah imposition that debt must be asset-backed which means a firm operating under Islamic principles cannot have debt exceeding the tangible assets. A firm with less tangible asset will therefore have relatively lower debt ratio (Ahmed, 2007). This condition implies that firms with more tangible assets will be able to have more debt relative to firms with fewer tangible assets. The positive relationship between 
tangibility and leverage also confirms the role of tangible assets in reducing the agency costs for outside investors, which in turn raises firm leverage. The finding is also similar to De Jong et al. (2008). Profitability is found to relate negatively with leverage $(\mathrm{p}=0.05) . \mathrm{H}_{3}$ is thus supported. Reflecting the pecking order theory high profit Shariah compliant SMEs in Malaysia do not need to depend so much on external funding as internally generated funds accumulated from past profit will be the first option and firms will opt to debt over equity if external funding is required. This finding confirmed the results documented by Manan et al. (2011) where a significant number of SMEs in Malaysia sought Islamic debt financing modes such as Murabahah, Bai' bithaman Ajil and Ijarah as alternatives when internal financing is no more sufficient.

Business risk is positively related to debt financing $(\mathrm{p}=0.10) . \mathrm{H}_{4}$ is thus supported. This result reflects the legal maxim 'Al kharaj bi al daman' highlighted by Obaidullah (2007) where it requires benefits (returns) and liabilities (risk) go together, that is, the higher the risk, the higher the return. Even though business risk is a proxy for the probability of financial distress or bankruptcy, the distress cost will be lower in the case of Shariah firm as debt is asset-backed thus minimizes the risks associated with debt financing (Ahmed, 2007).

The larger the size of these SMEs in Malaysia the more borrowing capacity thus the better bargaining power in seeking for lower cost of borrowing (Rajan and Zingales 1995). This notion is reflected by the positive relationship between firm size and debt financing $(\mathrm{p}=0.10)$ indicating the tendency of taking on more debt for larger SMEs, hence $\mathrm{H}_{5}$ is thus supported. Growth opportunities showed a negative relationship with leverage $(p=0.01)$, $\mathrm{H}_{6}$ is thus supported. SMEs in Malaysia with good growth opportunities seem to have lower debt ratio and this is perhaps due to a good and encouraging business during the period under study thus retained earnings are suffice to finance their operation. This finding suggests that growing Shariah compliant SMEs in Malaysia which are seeking to reduce the costs of asymmetric information would practice hierarchical financing thus, firms that have good investment opportunities but lack internal cash flow could turn to debt to fund their projects. Liquidity is found to be negatively related to debt financing $(\mathrm{p}=0.05) . \mathrm{H}_{7}$ is thus supported. Deesomsak et al. (2009) argue that liquid assets may be used as source of financing and these SMEs in Malaysia seem to consider these liquid assets in their debt financing decision. Share price performance appears to be positively related with leverage $(\mathrm{p}=0.01) . \mathrm{H}_{8}$ is thus supported. This finding confirmed Deesomsak et al. (2009) argument that firms whose shares are perceived to under-perform tend to issue shorter-term debt to signal their quality to the market, while firms whose shares are perceived to over-perform issue longer term debt to exploit the market mispricing.

This study reveals that Shariah compliance SMEs adjust to long term targets debt financing from time to time at the speeds of 0.8023 (1.25 year), 0.4254 (2.35 year) and 0.2138 (4.68 year) for total debt, long term debt and short term debt respectively to be at the target debt financing $\left(\mathrm{d}_{\mathrm{it}}=1-\mathrm{1}_{0} ; 1 / \mathrm{d}_{\mathrm{it}}\right) . \mathrm{H}_{9}$ is thus supported. Such rapid adjustment towards target debt financing suggests the existence of dynamic trade-off theory (Haron et al., 2013). 
Factors Affecting Speed of Adjustment

Table 2: Firm Specific Factors Affecting Speed of Adjustment

\begin{tabular}{ll}
\hline Independent Variable & Coefficient \\
\hline Lev (-1) & -1.4078 \\
& {$[-0.8861]$} \\
Lev(-1) x Distance & $1.6762^{* * *}$ \\
& {$[3.7053]$} \\
Lev(-1) x Firm Size & 0.0712 \\
& {$[0.8276]$} \\
Lev(-1) X Growth & -0.0042 \\
& {$[-0.3378]$} \\
Lev(-1) x Profitability & 0.2245 \\
& {$[0.6082]$} \\
\hline AR(1) ) m-Statistic & -2.3976 \\
AR(2) ) m-Statistic & {$[-0.2893]$} \\
& -0.8944 \\
Wald(Joint) $\chi^{2}$ & {$[-0.0644]$} \\
J-statistic & $100.8946^{* * *}$ \\
& $61.7382^{* * *}$ \\
No. of Observations & 14.2102 \\
\hline
\end{tabular}

Source: Author's own.

It is to note here that, referring to the empirical results presented in Table 2, Equation (11) under the methodology specifies a negative sign on the coefficient of the interaction term between Leverage(-1) and firm specific determinants, that is, $-Z_{i t} Y_{i t-1}$ and therefore the signs of the estimated coefficients on the respective interaction terms must be interpreted accordingly. In relation to this, as stated by Drobetz and Wanzenried (2006), a negative sign in the interaction term as shown in the regression output implies a positive relationship and a positive sign, implies a negative relationship.

The results show strong evidence on the negative relationship $(\mathrm{p}=0.01)$ between distance (DIST) and the speed of adjustment for the SMEs understudy, thus implying that these firms adjust faster if their actual debt level is not far from target debt. $\mathrm{H}_{10}$ is thus supported. The same negative relationship is also recorded by Banerjee et al. (2004) and Aybar-Arias et al. (2011). This result supports the argument that, if the fixed costs of adjustments are excessively high, firms will avoid approaching the capital market and adjust internally rather than using outside financing. Results on firm size, growth and profitability are however insignificant.

\section{CONCLUSION}

This study employed a dynamic framework in examining the debt financing of 41 Shariah compliance E50 SMEs from 2009 until 2013. Results showed that these SMEs confirmed the presumption that firms pursue target debt financing but get deviated from time to time due to firm specific factors. These SMEs did take into account several firm level determinants like tangibility, profitability, business risk, size, growth, liquidity and share 
price performance in the debt financing decision and results did indicate inclination to Shariah compliant characteristics of these SMEs. The significant impacts of these determinants reflect the influence of the pecking order theory where internal financing is very much preferred in their capital structure decisions thus confirms majority of past studies done on SMEs regardless of the economic landscapes.

This study also depicted high level of short term debt among these Shariah compliant SMEs. Again the finding on the high level of short term debt repeats what has been documented in the body of knowledge pertaining to financing decisions of SMEs. Aggarwal and Yousef (2000) propose agency costs and moral hazard as an explanation for the preference for shortterm lending by banks in Islamic countries. This study also investigated factors affecting speed of adjustment. Strong evidence on rapid speed of adjustment is recorded among the firms when they are not far from the target with under-levered firms adjust faster than the over-levered ones. Rapid adjustment speeds using internal funding indicated by the negative relationship between profitability and debt showing an influence of pecking order hypothesis in deciding on the readjustment process.

By employing a robust econometric model (GMM), this study contributes to the literature by exploring into a relatively new area of capital structure which is the dynamic aspects and the results of this study will also help to enhance the understanding on corporate financing behaviour of Shariah compliant SMEs in Malaysia. This study enriches the literature by filling the gap of capital structure studies based on the dynamic model and distinct this study from the existing ones in the literature. The findings will contribute significantly to the body of knowledge as well as to practitioners and also perhaps to financing resources of the SMEs.

\section{REFERENCES}

Abraham, A. (2013). Foreign ownership and bank performance metrics in Saudi Arabia. International Journal of Islamic and Middle Eastern Finance and Management, 6(1), 43-50.

Aggarwal, R. and Yousef, T. (2000). Islamic banks and investment financing. Journal of Money, Credit and Banking, 32 (1), 93-120.

Ahmed, H. (2007). Issues in Islamic corporate financing: capital structure in firms. Islamic Research and Training Institute (IRTI) Research Paper Series, (70), 1-48.

Arellano, M. and Bond, S.R. (1991). Some tests of specification for panel data: Monte Carlo evidence and application to employment equations. Review of Economic Studies, 58(2), 277-297.

Arinaitwe, S. K. (2006). Factors constraining the growth and survival of small scale businesses: A developing countries analysis. The Journal of American Academy of Business Cambridge, 8(2), 167-178.

Aybar-Arias, C., Martinez, A.C. and Gracia, J.L. (2011). On the adjustment speed of SMES to their optimal capital structure. Small Business Economic, 1-20. 
Banerjee, S., Heshmati, A. and Wihlborg, C. (2004). The dynamics of capital structure. Research in Banking and Finance, 4, 275-97.

Beck, T., Demirgüç-Kunt, A. and Singer, D. (2013). Is Small Beautiful? Financial structure, size and access to finance. World Development, 52, 19-33.

Behr, P., Entzian, A., and Guettler, A. (2011). How do lending relationships affect access to credit and loan conditions in microlending? Journal of Banking and Finance, 35(8), 2169-2178.

Boocock, G and Shariff, M.N.M. (2005). Measuring the effectiveness of credit guarantee schemes: evidence from Malaysia. International Small Business Journal, 23 (4), 427-454.

Cook, P. (2001). Finance and small-medium sized enterprise in developing countries. Journal of Developmental Entrepreneurship, 6(1), 17-40.

De Jong, A., Kabir, R. and Nguyen, T.T. (2008). Capital structure around the world: the roles of firm-and country-specific determinants. Journal of Banking and Finance, 32, 19541969.

Deesomsak, R., Paudyal, K. and Pescetto, G. (2009). Debt maturity structure and the 1997 Asian financial crisis. Journal of Multinational Financial Management, 19, 26-42.

Derigs, U. and Marzban, S. (2008). Review and analysis of current Shariah-compliant equity screening practices. International Journal of Islamic and Middle Eastern Finance and Management, 1(4), 285-303.

Drobetz, W. and Wanzenried, G. (2006). What determines the speed of adjustment to the target capital structure? Applied Financial Economics, 16, 941-958.

Haron, R. (2014). Capital structure inconclusiveness: evidence from Malaysia, Thailand and Singapore. International Journal of Managerial Finance, 10(1), 23-38.

Firms' speed of adjustment and rational financing behaviour: Malaysian evidence. Journal for Global Business Advancement, 7(2), 151-162.

Haron, R., Ibrahim, K., Mat Nor, F. and Ibrahim, I. (2013). Dynamic adjustment towards target capital structure: Thailand evidence. Jurnal Pengurusan, 39, 73-82.

Harvie, C., Narjoko, D. and Oum, S. (2013). Small and Medium Enterprises' access to finance: evidence from selected Asian economies. ERIA Discussion Paper Series, ERIADP-2013-23, 2013.

Ismail, A.G. and Razak.A.A. (2003). Equity or debt as a security choice: Evidence from smallmedium firms in Malaysia. International Journal of Management, 20(3), 408-417.

Mac an Bhaird, C. (2010). The Modigliani-Miller proposition after fifty years and its relation to entrepreneurial finance. Strategic Change, 19, 9-28.

Manan S.K.A., Othman, J., and Shahadan, A. (2011). Descriptive analysis on the pattern of SME financing in Malaysia, 3rd International Symposium \& Exhibition in Sustainable Energy \& Environment, 139-147. 
Mitchell, F. and Reid, G. (2000). Problems, challenges and opportunities: small business as a setting for management accounting research. Management Accounting Research, 11(4), $385-390$.

Modigliani, F. and Miller, M. (1958). The cost of capital, corporation finance, and the theory of investment. American Economic Review, 48, 261-297.

Obaidullah, M. (2007). Teaching corporate finance from an Islamic perspective. Islamic Economics Research Centre, King Abdul Aziz University.

Omet, G. and Mashharawe, F. (2003). The capital structure choice in tax contrasting environments: evidence from the Jordanian, Kuwaiti, Omani and Saudi corporate sectors, Working Paper, The Hashemite University, Amman.

Rajan, R.G. and Zingales, L. (1995). What do we know about capital structure? Some evidence from international data. Journal of Finance, 50, 1421-1460.

Saarani, A.N. and Shahadan, F. (2013). The comparison of capital structure determinants between Small And Medium Enterprises (SMEs) and large firms in Malaysia. International Journal of Economics and Finance Studies, 5(1), 64-73.

Securities Commission of Malaysia (2010). http://www.sc.com.my/

Shen, Y., M. Shen, Z. Xu, and Y. Bai. (2009). Bank size and Small- and Medium-sized Enterprise (SME) lending: evidence from China. World Development, 37(4), 800-811.

Titman, S. and Wessels, R. (1988). The determinants of capital structure choice. Journal of Finance 43, 1-19. 